\title{
Autocatalytic peptide bond cleavages in prothrombin and meizothrombin
}

Citation for published version (APA):

Petrovan, R. J., Govers-Riemslag, J. W. P., Nowak, G., Hemker, H. C., Tans, G., \& Rosing, J. (1998).

Autocatalytic peptide bond cleavages in prothrombin and meizothrombin. Biochemistry, 37(5), 1185-1191. https://doi.org/10.1021/bi971948h

Document status and date:

Published: 03/02/1998

DOI:

10.1021/bi971948h

Document Version:

Publisher's PDF, also known as Version of record

\section{Please check the document version of this publication:}

- A submitted manuscript is the version of the article upon submission and before peer-review. There can be important differences between the submitted version and the official published version of record.

People interested in the research are advised to contact the author for the final version of the publication, or visit the DOI to the publisher's website.

- The final author version and the galley proof are versions of the publication after peer review.

- The final published version features the final layout of the paper including the volume, issue and page numbers.

Link to publication

\footnotetext{
General rights rights.

- You may freely distribute the URL identifying the publication in the public portal. please follow below link for the End User Agreement:

www.umlib.nl/taverne-license

Take down policy

If you believe that this document breaches copyright please contact us at:

repository@maastrichtuniversity.nl

providing details and we will investigate your claim.
}

Copyright and moral rights for the publications made accessible in the public portal are retained by the authors and/or other copyright owners and it is a condition of accessing publications that users recognise and abide by the legal requirements associated with these

- Users may download and print one copy of any publication from the public portal for the purpose of private study or research.

- You may not further distribute the material or use it for any profit-making activity or commercial gain

If the publication is distributed under the terms of Article $25 \mathrm{fa}$ of the Dutch Copyright Act, indicated by the "Taverne" license above, 


\title{
Autocatalytic Peptide Bond Cleavages in Prothrombin and Meizothrombin ${ }^{\dagger}$
}

\author{
Ramona J. Petrovan, ${ }^{\ddagger}$ J José W. P. Govers-Riemslag, ${ }^{\ddagger}$ Götz Nowak," H. Coenraad Hemker,‡ Guido Tans, ${ }^{\ddagger}$ and \\ Jan Rosing*,: \\ Cardiovascular Research Institute Maastricht, Maastricht University, The Netherlands, and Max-Planck-Gesellschaft e.V., \\ "Pharmacological Haemostaseology", Friedrich Schiller University, Jena, Germany
}

Received August 6, 1997

\begin{abstract}
During factor Xa-catalyzed prothrombin activation, several other reaction products accumulate as a result of proteolysis of prothrombin and its activation products by thrombin and meizothrombin. Gel electrophoretic analysis and N-terminal sequencing of reaction products showed that in the absence of $\mathrm{Ca}^{2+}$ ions thrombin cleaved the following peptide bonds: $\mathrm{Arg}^{51}-\mathrm{Thr}^{52} / \mathrm{Arg}^{54}-\mathrm{Asp}^{55}$ in the fragment 1 (F1) domain $\left(k=0.4 \times 10^{4} \mathrm{M}^{-1} \mathrm{~s}^{-1}\right)$, Arg ${ }^{155}-\operatorname{Ser}^{156}$ in prothrombin $\left(k=2 \times 10^{4} \mathrm{M}^{-1} \mathrm{~s}^{-1}\right)$, and $\operatorname{Arg}^{284}-\mathrm{Thr}^{285}$ in prethrombin $1\left(k=0.02 \times 10^{4} \mathrm{M}^{-1} \mathrm{~s}^{-1}\right)$. In the presence of $2.5 \mathrm{mM} \mathrm{CaCl}_{2}$, cleavage in fragment 1 ( $\mathrm{Arg}^{51}-\mathrm{Thr}^{52} / \mathrm{Arg}^{54}-\mathrm{Asp}^{55}$ ) was not detectable, whereas cleavage at $\mathrm{Arg}^{155}-\mathrm{Ser}^{156}$ (i.e., removal of F1) was inhibited 25-fold. Cleavage at $\mathrm{Arg}^{284}-\mathrm{Thr}^{285}$ (formation of prethrombin 2 des-113) was not affected by the presence of $\mathrm{Ca}^{2+}$ ions. Meizothrombin rapidly converted itself into meizothrombin des-F1. The half-life $\left(t_{1 / 2}=\sim 30 \mathrm{~s}\right)$ of this reaction was independent of the meizothrombin concentration $(0.1-1 \mu \mathrm{M}$ meizothrombin), which is indicative for intramolecular autocatalysis $(k=0.02$ $\mathrm{s}^{-1}$ in the presence of $2.5 \mathrm{mM} \mathrm{Ca}^{2+}$ ions). Since the rapid removal of fragment 1 precludes investigations of the cleavage at $\mathrm{Arg}^{284}-\mathrm{Thr}^{285}$ in intact meizothrombin, we analyzed the cleavage of this peptide bond in R155A-meizothrombin, a recombinant product that is resistant to autocatalytic removal of the fragment 1 domain. In the absence of phospholipids, R155A-meizothrombin converted itself into thrombin des$1-13$ by a combination of intramolecular $\left(k=0.8 \times 10^{-4} \mathrm{~s}^{-1}\right)$ and intermolecular autocatalysis $(k=0.2$ $\times 10^{3} \mathrm{M}^{-1} \mathrm{~s}^{-1}$ ). Intramolecular autocatalytic conversion of R155A-meizothrombin into thrombin was not affected by the presence of phospholipids $\left(k=0.8 \times 10^{-4} \mathrm{~s}^{-1}\right)$, whereas intermolecular autocatalysis was accelerated 25 -fold $\left(k=5.6 \times 10^{3} \mathrm{M}^{-1} \mathrm{~s}^{-1}\right)$ by phospholipid vesicles. Since factor $\mathrm{Xa} / \mathrm{Va}$-catalyzed conversion of meizothrombin into thrombin occurs with $k=5.5 \times 10^{8} \mathrm{M}^{-1} \mathrm{~s}^{-1}$, we conclude that in reaction systems containing purified proteins autocatalysis of meizothrombin hardly contributes to thrombin formation during factor Xa-catalyzed prothrombin activation.
\end{abstract}

The conversion of the zymogen prothrombin into its active form thrombin is one of the central reactions of blood coagulation. Thrombin formation is the result of cleavage of two peptide bonds at $\mathrm{Arg}^{271}$ and $\mathrm{Arg}^{320}$ in prothrombin ${ }^{1}$ by blood coagulation factor Xa (Suttie \& Jackson, 1977; Heldebrant et al., 1973; Downing et al., 1975). Dependent

$\dagger$ This work was supported by Program Grant 900-526-192 from the Dutch Organisation for Scientific Research (NWO).

* To whom correspondence should be addressed: Department of Biochemistry, Maastricht University, P.O. Box 616, 6200 MD Maastricht, The Netherlands. Tel: 31-43-3881678. Fax: 31-43-3670988.

$\doteqdot$ Maastricht University.

$\S$ On leave of absence from Max-Planck-Gesellschaft e.V., Unit for "Pharmacological Haemostaseology" at the Friedrich Schiller University, Jena, Germany. Supported by Deutscher Akademischer Austauschdienst and Deutsche Akademie der Naturforscher "Leopoldina".

${ }^{1}$ The numbering used corresponds to the cDNA sequence coding for the human prothrombin (cf. Degen \& Davie, 1987). Human prothrombin consists of 579 residues whereas bovine prothrombin contains 582 residues. Consequently, the numbering of amino acids of human prothrombin differs by three residues from that of the bovine molecule. on the order of cleavage, two activation pathways are possible and both intermediates, prethrombin 2 (Esmon et al., 1974; Rosing et al., 1980) and meizothrombin (Krishnaswamy et al., 1986; Rosing et al., 1986) are detected during prothrombin activation. Prethrombin 2 has no catalytic activity, while meizothrombin, a two-chain molecule with the same molecular weight as prothrombin, exhibits full esterolytic and amidolytic activity toward small substrates. Compared with thrombin, meizothrombin has reduced activity on macromolecular thrombin substrates (Rhee et al., 1982; Krishnaswamy et al.,1986; Doyle \& Mann, 1990), which may be enhanced, however, by the presence of negatively charged phospholipids (Tans et al., 1994).

A clear description of product generation during prothrombin activation is difficult because of very effective autocatalytic degradation of prothrombin and prothrombin activation products. Thrombin and meizothrombin are capable of a feedback reaction at $\mathrm{Arg}^{155}-\mathrm{Ser}^{156}$ bond in prothrombin or meizothrombin. This results in the removal of fragment 1 $(\mathrm{F} 1)^{2}$ and generation of prethrombin 1 or meizothrombin des- 
F1 (Doyle \& Mann, 1990; Esmon et al., 1974). Autoproteolysis at $\mathrm{Arg}^{284}$ in human prothrombin will give rise to a form of thrombin (thrombin des-1-13), with a 13 amino acid shorter A-chain, which has the same catalytic properties as $\alpha$-thrombin (Downing et al., 1975; Lanchantin et al., 1973). When this cleavage occurs in meizothrombin, fragment 1.2.3 and thrombin des-1-13 are liberated (Doyle \& Mann, 1990 ; Rabiet et al., 1986). Other thrombin cleavage sites within fragment 1 have been reported at $\mathrm{Arg}^{51}$ (Walz et al., 1977) and at $\operatorname{Arg}^{54}$ (Board \& Shaw, 1983). The latter cleavage was recently reported as $\mathrm{Arg}^{55}-\mathrm{Asp}^{56}$ by Stevens et al. (1996) in a recombinant stable meizothrombin with the cleavage site mutations R155A, R271A, and R284A (in the human cDNA numbering ${ }^{1}$ this is, however, $\operatorname{Arg}^{54}$ $\mathrm{Asp}^{55}$ ). In thrombin, a number of additional bonds can be cleaved by autocatalysis at the carboxyl-terminus of the molecule (B-chain), resulting in forms of thrombin $(\beta$ - and $\gamma$-thrombin) with reduced procoagulant activity (Boissel et al., 1984).

In plasma or whole blood only low amounts of fragment 1 (Rabiet et al., 1986; Aronson et al., 1977) or meizothrombin (Tans et al., 1991) accumulate. This suggests the presence of additional mechanisms which may protect prothrombin from feedback proteolysis and alter the peptide bond cleavage pattern during plasma prothrombin activation. To allow evaluation of feedback reactions during prothrombin activation, we determined in a model system the rate constants of autocatalytic cleavages in prothrombin and R155A-prothrombin, a recombinant prothrombin in which $\operatorname{Arg}^{155}$ is replaced by Ala and which, due to the amino acid substitution, cannot be converted into prethrombin 1 or meizothrombin des-F1. This study was undertaken in order to elucidate the possible physiological significance of feedback and/or autocatalytic reactions during in vivo prothrombin activation.

\section{EXPERIMENTAL PROCEDURES}

Materials. Hepes, Tris, EDTA, bovine serum albumin, and ovalbumin were purchased from Sigma Chemical Co. DOPC and DOPS were obtained from Avanti Polar Lipids, Pelham, AL. Small unilamellar phospholipid vesicles were prepared as decribed before (Rosing et al., 1980). The chromogenic substrate S2238 and the reversible thrombin inhibitor I2581 were supplied by Chromogenix, Mölndal, Sweden. Ecarin, the prothrombin activator from Echis carinatus venom, was purchased from Pentapharm, Switzerland. Heparin (USP activity 175 units/mg) was purchased from Organon. PPACK was obtained from Calbiochem, and $p$-NPGB was from Nutritional Biochemicals. Micro BCA protein assay kits were from Pierce, Rockford. Immobilon-P membranes were obtained from Millipore, Bedford, MA. Antibodies were supplied by Kordia, The Netherlands, and Sigma Chemical Co. Rabbit antihuman F1.2 was a kind gift of Dr. T. Lindhout, Maastricht University, The Netherlands.

\footnotetext{
2 Abbreviations: AT-III, antithrombin III; BCA, bicinchoninic acid; BSA, bovine serum albumin; DOPC, 1,2-dioleoyl-sn-glycero-3-phosphocholine; DOPS, 1,2-dioleoyl-sn-glycero-3-phosphoserine; F1, fragment $1 ; \mathrm{F} 1.2$, fragment $1.2 ; p$-NPGB, $p$-nitrophenyl $p^{\prime}$-guanidinobenzoate hydrochloride; SDS, sodium dodecyl sulfate; SDS-PAGE, polyacrylamide gel electrophoresis in the presence of SDS; S2238, D-Phe-(pipecolyl)-Arg-pNA; prethrombin 2 des-1-13, prethrombin 2 lacking $\mathrm{Thr}^{272}-\mathrm{Arg}^{284}$; thrombin des-1-13, thrombin lacking $\mathrm{Thr}^{272}$ $\mathrm{Arg}^{284}$; PPACK, phenylalanyl-prolyl-arginine chloromethyl ketone.
}

Materials used for protein purification were purchased from Pharmacia.

Proteins. The human coagulation factors used in this study were purified from fresh frozen plasma. Human prothrombin was purified according to DiScipio et al. (1977). Human thrombin was prepared from prothrombin activation mixtures by the method of Pletcher and Nelsestuen (1982). Recombinant prothrombin (R155A-prothrombin) was obtained and purified as described before (Tans et al., 1994). Human antithrombin III was isolated according to Thaler and Schmer (1975). Prethrombin 1 and fragment 1 were purified from a reaction mixture of human prothrombin with thrombin in $50 \mathrm{mM}$ Tris (pH 7.9) and $175 \mathrm{mM} \mathrm{NaCl}$. After inhibition of thrombin with PPACK, the reaction mixture was applied to a column (XK 5/10) with Q Sepharose fast flow. Prethrombin 1 did not adhere to the resin, and fragment 1 and noncleaved prothrombin were eluted with a gradient of 250 to $600 \mathrm{mM} \mathrm{NaCl}$. Fragment 1 was separated from prothrombin by gel permeation chromatography on a $\mathrm{Su}-$ perdex 200 HiLoad (16/60) column in $25 \mathrm{mM}$ Hepes (pH 7.7) and $175 \mathrm{mM} \mathrm{NaCl}$. R155A-meizothrombin, meizothrombin, and meizothrombin des-fragment 1 were obtained from reaction mixtures in which $\mathrm{R} 155 \mathrm{~A}$-prothrombin or prothrombin were incubated with purified prothrombin activators from Echis carinatus or Echis coloratus (Tans et al., 1994). Prothrombin, R155A-prothrombin, antithrombin III, prethrombin 1 , fragment 1 , and thrombin were stored at $-80^{\circ} \mathrm{C}$. Protein preparations were homogeneous and $>95 \%$ pure as judged by SDS-PAGE according to Laemmli (1970).

Protein Concentrations. Protein concentrations were determined with the micro BCA protein assay (Smith et al., 1985). Molar thrombin concentrations were determined by active site titration with $p$-NPGB (Chase \& Shaw, 1969). Prothrombin concentrations were determined after complete activation of prothrombin with Echis carinatus venom and quantitation of thrombin with $p$-NPGB. Meizothrombin and R155A-meizothrombin concentrations were determined with $\mathrm{S} 2238$, considering that the amidolytic activity per mole is the same as that of thrombin (Rosing et al., 1986; Doyle \& Mann, 1990).

Measurement of Prothrombin Activation. Amidolytic activity (thrombin, meizothrombin, and/or meizothrombin des-F1) generated during prothrombin activation was determined by transferring samples from reaction mixtures to cuvettes containing a final volume of $1 \mathrm{~mL}$ of $50 \mathrm{mM}$ Tris$\mathrm{HCl}$ (pH 7.9), $175 \mathrm{mM} \mathrm{NaCl}, 20 \mathrm{mM}$ EDTA, $0.5 \mathrm{mg} / \mathrm{mL}$ ovalbumin, and $235 \mu \mathrm{M} \mathrm{S} 2238$ at $37^{\circ} \mathrm{C}$, as described earlier (Rosing et al., 1986). Quantitation of meizothrombin plus meizothrombin des-F1 was performed in appropriate dilutions by measurement of the activity toward S2238, that remained after 1 min incubation with $5 \mathrm{nM}$ AT III in the presence of $30 \mu \mathrm{g} / \mathrm{mL}$ heparin, as described before (Rosing et al., 1986). This assay does not discriminate between meizothrombin and meizothrombin des-F1, since under the assay conditions they exhibit the same activity toward S2238 and are equally inhibited by AT-III plus heparin.

Gel Electrophoretic and Immunoblot Analysis. Products of prothrombin proteolysis were analyzed after SDS-PAGE on $13 \%$ slabgels according to Laemmli (1970) and identified after staining with Coomassie Brilliant Blue R-250 or after electrophoretic transfer of proteins from the gel to Immo- 


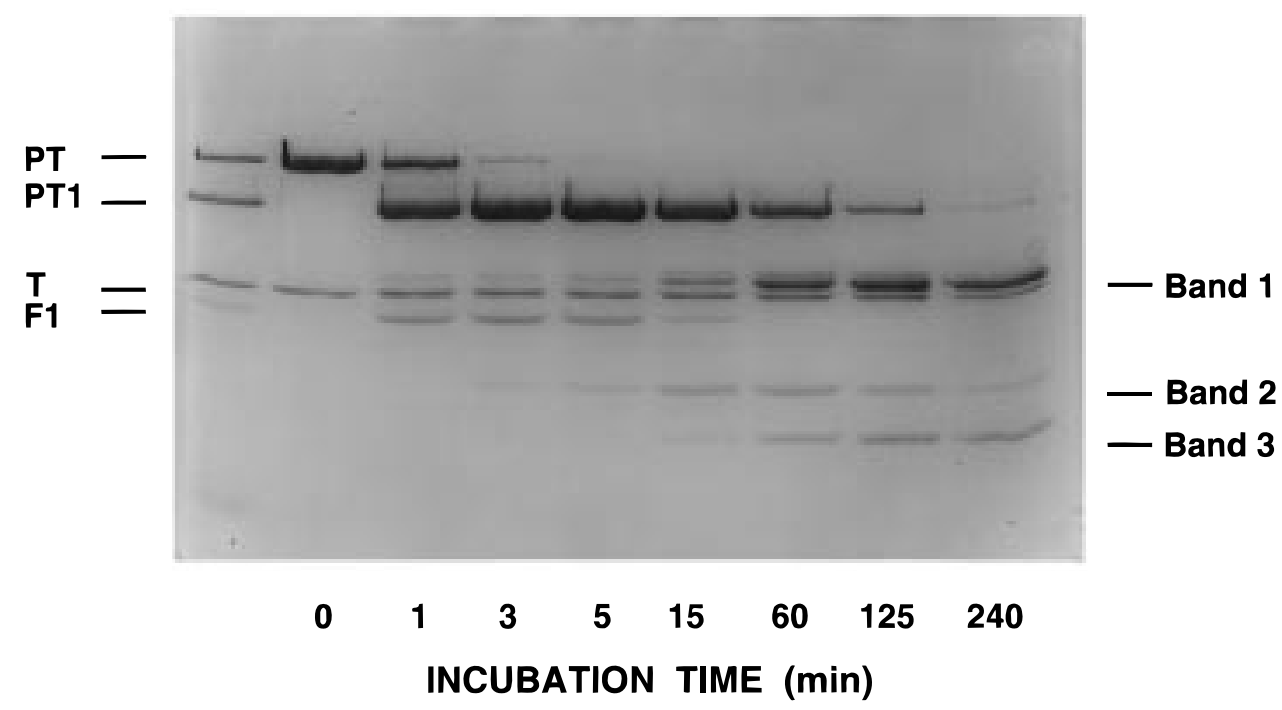

FIGURE 1: Gel electrophoretic analysis of proteolysis of prothrombin by thrombin. Prothrombin $(3 \mu \mathrm{M})$ was incubated with $0.75 \mu \mathrm{M}$ thrombin in a reaction mixture containing $25 \mathrm{mM}$ Hepes $(\mathrm{pH} 7.7)$ and $175 \mathrm{mM} \mathrm{NaCl}$ at $37{ }^{\circ} \mathrm{C}$. At the indicated times, aliquots of the reaction mixture were reduced with $5 \% \beta$-mercaptoethanol and subjected to SDS-PAGE on $13 \%$ gels. The gels were stained with Coomassie Brilliant Blue R-250. The left lane contains a reference mixture of prothrombin (PT), prethrombin 1 (PT 1), thrombin (T), and fragment 1 (F1). Further details are given in the Experimental procedures.

bilon-P membranes and visualization with a polyclonal rabbit-antibody directed against the human F1.2 and goat anti-rabbit IgG conjugated with alkaline phosphatase as described by Blake et al. (1984). The immunoblots were scanned on a Pharmacia Image Master DTS scanner and the amounts of proteins were quantified using the "Image Master 1D" program as percentage of staining intensity of the same protein bands in the sample taken at time zero. The relation between the staining intensity and the amount of protein on the gel was determined on separate gels that contained varying known amounts of prothrombin, prethrombin 1 , or fragment 1 per lane.

Amino-Terminal Sequence Analysis. Prothrombin $(5 \mu \mathrm{M})$ was incubated at $37{ }^{\circ} \mathrm{C}$ for $2 \mathrm{~h}$ with $2 \mu \mathrm{M}$ thrombin in the absence of $\mathrm{Ca}^{2+}$ in $25 \mathrm{mM}$ Hepes (pH 7.7) and $175 \mathrm{mM}$ $\mathrm{NaCl}$. The reaction products were separated by SDS-PAGE on $13 \%$ reduced gels, transfered to Immobilon-P membranes in $50 \mathrm{mM}$ Tris-borate $(\mathrm{pH} 8.4)$ and $20 \%$ methanol, and stained with diluted Coomassie Brilliant Blue R-250. Protein bands were cut from the blots and subjected to automated amino-terminal sequencing on a Procise 494 Sequencer from Applied Biosystems, Foster City, CA (Protein Laboratory, IMB-Jena Germany).

Kinetic Analysis of Time Courses of Proteolysis. Time courses of prothrombin, prethrombin1, meizothrombin, or fragment 1 proteolysis were followed by SDS-PAGE, immunoblotting, and quantitation of the intensity of the protein bands on the blots as described above. The fraction of substrate remaining at each time interval $\left(S_{t} / S_{0}\right)$ was plotted vs time and the pseudo-first-order rate constants $(k)$ were obtained by fitting the time courses of prothrombin, prethrombin 1, meizothrombin, or fragment 1 disappearance to a single exponential $\left(S_{\mathrm{t}}=S_{0} \mathrm{e}^{-k t}\right.$, in which $S_{0}=$ the intensity of the protein band at $T=0$ and $S_{\mathrm{t}}=$ the intensity of the protein band at $T=t$ ) using nonlinear least squares regression analysis. Second-order rate constants were obtained by dividing the pseudo-first-order rate constant by the enzyme concentration.

\section{RESULTS}

Peptide Bonds in Human Prothrombin Susceptible to Feedback Proteolysis by Thrombin. The time course of product generation during feedback reactions of thrombin on prothrombin was followed by SDS-PAGE and visualization of protein bands by staining with Coomassie Blue (Figure 1). In the absence of $\mathrm{Ca}^{2+}$ ions, considerable amounts of prethrombin 1 and fragment 1 were formed in the early phase of the incubation. Their concentration decreased after prolonged incubation with formation of products with lower molecular weights (designated band 1, 2, and 3, cf. Figure 1). The appearance of these bands is indicative for thrombin-catalyzed cleavages in prethrombin 1 and fragment 1.

Amino-terminal sequence analysis of the protein bands 1, 2 , and 3 formed during incubation of prothrombin with thrombin in the absence of $\mathrm{Ca}^{2+}$ yielded the following sequences: band 1, Thr-Phe-Gly-Ser-Gly-Glu-Ala-Asp, band 2, Ser-Glu-Gly-Ser-Ser-Val-Asn-Leu, and band 3, Thr-ProArg-Asp-Lys-Leu-Ala-Ala and Asp-Lys-Leu-Ala-Ala-?-LeuGlu. Comparison with the primary amino acid sequence of human prothrombin (Degen \& Davie, 1987) indicates that these products result from thrombin-catalyzed cleavages at $\mathrm{Arg}^{284}-\mathrm{Thr}^{285}$ in prethrombin 1 giving rise to prethrombin 2 des-1-13 (band 1) and fragment 2.3 (band 2) and at $\mathrm{Arg}^{51}-\mathrm{Thr}^{52}$ and $\mathrm{Arg}^{54}-\mathrm{Asp}^{55}$ in the fragment 1 region resulting in the formation of fragments with apparent $M_{\mathrm{r}} \approx$ $20 \mathrm{kDa}$ (band 3) and $7 \mathrm{kDa}$ (not visible on the gel) derived from fragment 1.

Effect of $\mathrm{Ca}^{2+}$ Ions on Proteolysis of Human Prothrombin, Prethrombin 1, and Fragment 1 by Thrombin. Earlier investigations on the removal of fragment 1 from bovine prothrombin by thrombin and on the cleavage at $\mathrm{Arg}^{54}$ Asp ${ }^{55}$ in recombinant meizothrombin demonstrated inhibition by $\mathrm{Ca}^{2+}$ (Silverberg, 1979; Stevens et al., 1996). To evaluate the effect of $\mathrm{Ca}^{2+}$ ions on the thrombin-catalyzed cleavages at $\mathrm{Arg}^{155}-\mathrm{Ser}^{156}, \mathrm{Arg}^{284}-\mathrm{Thr}^{285}$, and $\mathrm{Arg}^{51}-\mathrm{Thr}^{52} / \mathrm{Arg}^{54}-$ $A_{s p}{ }^{55}$, the disappearance of the substrates for these peptide 
Table 1: Rate Constants of Proteolytic Cleavages in Human Prothrombin ${ }^{a}$

\begin{tabular}{clllll}
\hline & & & & \multicolumn{2}{c}{$k\left(\mathrm{M}^{-1} \mathrm{~s}^{-1}\right)$} \\
\cline { 3 - 6 } substrate & enzyme & peptide bond & \multicolumn{1}{c}{ products $^{2+}$} & $2.5 \mathrm{mM} \mathrm{Ca}^{2+}$ \\
\hline PT & thrombin & $\operatorname{Arg}^{155}-\mathrm{Ser}^{156}$ & PT1, F1 & $2 \times 10^{4}$ & $0.08 \times 10^{4}$ \\
PT1 & thrombin & $\operatorname{Arg}^{284}-\mathrm{Thr}^{285}$ & PT2 des-1-13, F2.3 & $0.02 \times 10^{4}$ & $0.02 \times 10^{4}$ \\
F1 & thrombin & $\operatorname{Arg}^{51}-\mathrm{Thr}^{52}$ & $7 \mathrm{kDa}, 20 \mathrm{kDa}$ fragments & $0.4 \times 10^{4}$ & $<10$ \\
& & $\mathrm{Arg}^{54}-\mathrm{Asp}^{55}$ & & \\
\hline
\end{tabular}

${ }^{a}$ Rate constants of thrombin-catalyzed cleavage of human prothrombin, prethrombin 1, and fragment 1 were obtained by fitting the time courses presented in Figure 2 to a single exponential equation. Further experimental details are given in the Experimental Procedures. PT $=$ prothrombin, $\mathrm{PT} 1=$ prethrombin $1, \mathrm{~F} 1=$ fragment 1.
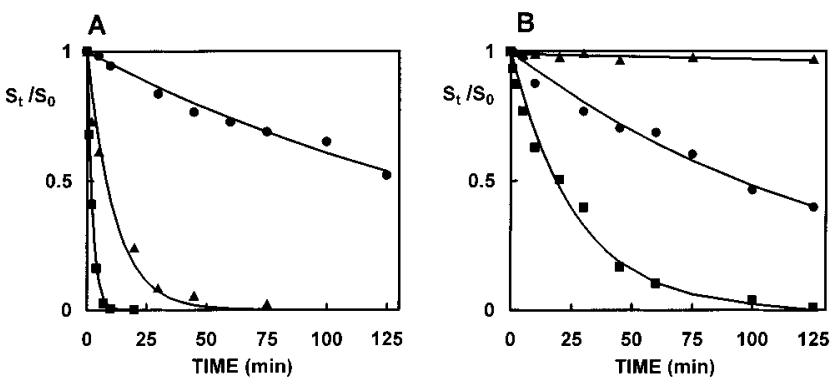

FIGURE 2: Time courses of prothrombin, prethrombin 1, and fragment 1 proteolysis by thrombin. Proteolysis of $0.5 \mu \mathrm{M}$ prothrombin $(\mathbf{\square})$, prethrombin $1(\boldsymbol{\bullet})$, or fragment 1 ( $\mathbf{\Delta})$ was followed at $37^{\circ} \mathrm{C}$ in reaction mixtures containing $25 \mathrm{mM}$ Hepes (pH 7.7), $175 \mathrm{mM} \mathrm{NaCl}$, and $0.4 \mu \mathrm{M}$ thrombin without $\mathrm{CaCl}_{2}$ (panel A) or $0.8 \mu \mathrm{M}$ thrombin in the presence of $2.5 \mathrm{mM} \mathrm{CaCl}_{2}$ (panel B). After various time intervals aliquots from the reaction mixture were diluted in SDS-electrophoresis buffer (with $5 \% \beta$-mercaptoethanol) and $10 \mu \mathrm{L}$ of these samples was subjected to SDSPAGE on $13 \%$ slab gels, immunoblotting and quantification of the staining intensity of protein bands as described in the Experimental Procedures. The solid lines represent exponential curves obtained by fitting the data to the equation given in the Experimental Procedures.

bond cleavages (prothrombin, prethrombin 1 and fragment 1) was followed by SDS-PAGE analysis, immunoblotting, and staining of the protein bands with appropriate antibodies. From calibration curves obtained in a separate experiment, a linear relationship was established between the staining intensity of prothrombin, prethrombin 1, or fragment 1 and the amount of protein on the blot (data not shown), and therefore, quantification of the protein bands via scanning of immunoblots of time courses was used to determine the rate of peptide bond cleavages in prothrombin, prethrombin 1 and fragment 1.

Figure 2A shows the time courses of thrombin-catalyzed cleavages in prothrombin, prethrombin 1 , and fragment 1 in the absence of $\mathrm{Ca}^{2+}$ ions. The time courses could be fitted with a single exponential equation and yielded pseudo-firstorder rate constants for thrombin-catalyzed cleavages at $\mathrm{Arg}^{51}-\mathrm{Thr}^{52} / \mathrm{Arg}^{54}-\mathrm{Asp}^{55}, \mathrm{Arg}^{155}-\mathrm{Ser}^{156}$, and $\mathrm{Arg}^{284}-\mathrm{Thr}^{285}$. Variation of the concentrations of reactants showed that the rates of peptide bond cleavages were first-order in both substrate $(0-2 \mu \mathrm{M}$ prothrombin, prethrombin 1 , or fragment $1)$ and enzyme ( $0-2 \mu \mathrm{M}$ thrombin). This allows calculation of second-order rate constants (Table 1) from the pseudofirst-order rate constants obtained from the exponential fits.

In the presence of $\mathrm{Ca}^{2+}$ ions (Figure 2B), proteolysis in fragment 1 was completely inhibited and proteolysis of human prothrombin to prethrombin 1 and fragment 1 was slowed down about 25-fold, whereas no significant changes of the rate of cleavage at $\mathrm{Arg}^{284}-\mathrm{Thr}^{285}$ in prethrombin 1 were observed (Table 1).

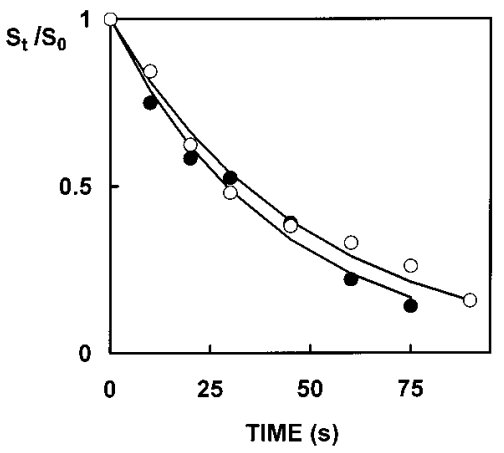

FIGURE 3: Time courses of autocatalytic removal of fragment 1 from meizothrombin. Meizothrombin $(0.5 \mu \mathrm{M})$ was incubated at $37^{\circ} \mathrm{C}$ in reaction mixtures containing $25 \mathrm{mM}$ Hepes (pH 7.7), 175 $\mathrm{mM} \mathrm{NaCl}, 2.5 \mathrm{mM} \mathrm{CaCl} 2$, and no phospholipid (O) or $25 \mu \mathrm{M}$ DOPS/DOPC $(25 / 75, \mathrm{~mol} / \mathrm{mol})$ vesicles $(\boldsymbol{\bullet})$. After various time intervals aliquots from the reaction mixture were diluted in SDSelectrophoresis buffer (with $5 \% \beta$-mercaptoethanol) and $10 \mu \mathrm{L}$ of these samples was subjected to SDS-PAGE on $13 \%$ slab gels, immunoblotting, and quantification of the staining intensity of the meizothrombin band as described in the Experimental Procedures. The solid lines represent exponential curves obtained by fitting the data to the equation given in the Experimental Procedures.

Autocatalytic Conversion of Meizothrombin. The observation that thrombin can cleave the $\mathrm{Arg}^{284}-\mathrm{Thr}^{285}$ bond in prothrombin/prethrombin 1 encouraged us to test whether meizothrombin can also cleave this peptide bond in itself and thus contribute to thrombin formation (thrombin des$1-13)$ via autocatalysis. Meizothrombin is a reaction intermediate that is formed in the early phase of factor Xacatalyzed prothrombin activation and that is subsequently converted into thrombin (Rosing et al., 1986; Krishnaswamy et al., 1986). However, human meizothrombin is rapidly converted into meizothrombin des-F1 by autocatalytic feedback cleavage (Doyle \& Mann, 1990). Since meizothrombin des-F1 lacks the gla-containing phospholipid-binding domain this reaction precludes studies of the autocatalytic cleavage at $\mathrm{Arg}^{284}-\mathrm{Thr}^{285}$ in intact meizothrombin, especially in the presence of phospholipids.

Therefore, we first determined the rate constant for conversion of meizothrombin into meizothrombin des-F1 (Figure 3). Time courses of meizothrombin disappearance in the absence and presence of phospholipids were fitted to a single exponentional equation and it appeared that phospholipids did not influence the rate of conversion of meizothrombin into meizothrombin des-F1 (Figure 3, Table 2 ). Since the half-life of meizothrombin was independent of the concentration $(0.1-1 \mu \mathrm{M}$ meizothrombin, data not shown), we conclude that the removal of fragment 1 from meizothrombin is a first-order reaction in which each meizothrombin molecule cleaves off its own fragment 1 
Table 2: Rate Constants of Peptide Bond Cleavages in Meizothrombin ${ }^{a}$

\begin{tabular}{|c|c|c|c|c|c|c|c|}
\hline \multirow[b]{2}{*}{ substrate } & \multirow[b]{2}{*}{ enzyme } & \multirow[b]{2}{*}{ cleavage site } & \multirow[b]{2}{*}{ product } & \multicolumn{2}{|c|}{ no PL } & \multicolumn{2}{|c|}{$+25 \mu \mathrm{M}$ PL } \\
\hline & & & & $k_{1}\left(\mathrm{~s}^{-1}\right)$ & $k_{2}\left(\mathrm{M}^{-1} \mathrm{~s}^{-1}\right)$ & $k_{1}\left(\mathrm{~s}^{-1}\right)$ & $k_{2}\left(\mathrm{M}^{-1} \mathrm{~s}^{-1}\right)$ \\
\hline MT & MT & $\operatorname{Arg}^{155}-\operatorname{Ser}^{156}$ & MT des-F1, F1 & $207 \times 10^{-4}$ & & $245 \times 10^{-4}$ & \\
\hline MT des-F1 & MT des-F1 & $\operatorname{Arg}^{284}-\mathrm{Thr}^{285}$ & $\mathrm{~T}$ des- $1-13, \mathrm{~F} 2.3$ & $0.7 \times 10^{-4}$ & $0.4 \times 10^{3}$ & $0.8 \times 10^{-4}$ & $0.3 \times 10^{3}$ \\
\hline R155A-MT & R155A-MT & $\operatorname{Arg}^{284}-\operatorname{Thr}^{285}$ & $\mathrm{~T}$ des- $1-13, \mathrm{~F} 1.2 .3$ & $0.8 \times 10^{-4}$ & $0.2 \times 10^{3}$ & $0.8 \times 10^{-4}$ & $5.6 \times 10^{3}$ \\
\hline R155A-MT & $\mathrm{FXa} / \mathrm{Va}$ & $\operatorname{Arg}^{271}-\mathrm{Thr}^{272}$ & $\mathrm{~T}, \mathrm{~F} 1.2$ & & nd & & $5.5 \times 10^{8}$ \\
\hline
\end{tabular}

${ }^{a}$ Rate constants of intramolecular $\left(k_{1}\right)$ and intermolecular $\left(k_{2}\right)$ autocatalytic cleavage in meizothrombin and R155A-meizothrombin were obtained from plots of $k_{\mathrm{obs}}$ as function of the meizothrombin concentration (Figure 5). Second-order rate constants of factor Xa/Va-catalyzed conversion of R155A-meizothrombin into thrombin were obtained from initial rates of thrombin formation. MT $=$ meizothrombin, $\mathrm{T}=$ thrombin, $\mathrm{F} 1=$ fragment $1, \mathrm{~F} 1.2=$ fragment $1.2, \mathrm{~F} 1.2 .3=$ fragment $1.2 .3, \mathrm{~F} 2.3=$ fragment 2.3 , nd $=$ not determined.
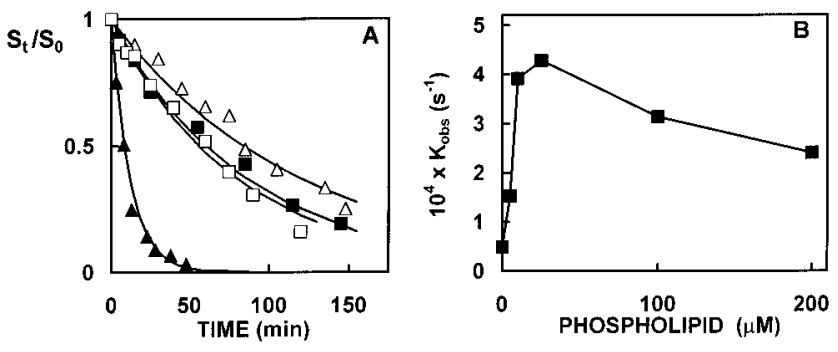

FIGURE 4: Effect of phospholipid on the autocatalytic conversion of meizothrombin des-F1 and R155A-meizothrombin into thrombin des-1-13. (A) Meizothrombin $(0.25 \mu \mathrm{M})$ des-F1 $(\square, \boldsymbol{\square})$ or R155Ameizothrombin $(\triangle, \mathbf{\Delta})$ were incubated at $37^{\circ} \mathrm{C}$ in a reaction mixture containing $25 \mathrm{mM}$ Hepes ( $\mathrm{pH} 7.7), 175 \mathrm{mM} \mathrm{NaCl}, 0.5 \mathrm{mg} / \mathrm{mL}$ ovalbumin, $2.5 \mathrm{mM} \mathrm{CaCl}_{2}$, and no phospholipids $(\square, \triangle)$ or $25 \mu \mathrm{M}$ DOPS/DOPC $(25 / 75, \mathrm{~mol} / \mathrm{mol})$ vesicles $(\boldsymbol{\square}, \mathbf{\Delta})$. At the time intervals indicated, aliquots were withdrawn for analysis of thrombin formation as described in the Experimental Procedures. The solid lines represent exponential curves obtained by fitting the data to the equation given in the Experimental Procedures. (B) Pseudofirst-order rate constants $\left(k_{\text {obs }}\right)$ obtained from exponential fits of time courses of $0.25 \mu \mathrm{M}$ R155A-meizothrombin dissappearance at varying amounts of DOPS/DOPC $(25 / 75, \mathrm{~mol} / \mathrm{mol})$ vesicles.

domain via intramolecular autocatalysis [see Sanny et al. (1975) for intramolecular autoactivation of pepsinogen]. A similar mechanism of autocatalysis was recently also reported for the cleavage at $\mathrm{Arg}^{54}-\mathrm{Asp}^{55}$ (Stevens et al., 1996).

The rates of peptide bond cleavage at $\mathrm{Arg}^{284}$ were determined in meizothrombin des-F1 and in R155A-meizothrombin, derived from a recombinant prothrombin that is resistant to removal of fragment 1 (Tans et al., 1994). Figure 4A shows time courses of autocatalytic conversion of 0.25 $\mu \mathrm{M}$ meizothrombin des-F1 or R155A-meizothrombin into thrombin in the absence and presence of phospholipids. In the absence of negatively charged phospholipid vesicles, meizothrombin des-F1 and R155A-meizothrombin were converted into thrombin at similar rates. The presence of phospholipids hardly affected autocatalytic conversion of meizothrombin des-F1 into thrombin. In contrast, in the case of R155A-meizothrombin, the presence of $25 \mu \mathrm{M}$ phospholipids considerably stimulated autocatalytic thrombin formation (Figure 4A). The phospholipid stimulation of autocatalytic conversion of R155A-meizothrombin into thrombin appeared to be dependent on the phospholipid concentration, and optimal rates of autocatalytic thrombin formation were observed at $\sim 20 \mu \mathrm{M}$ phospholipid (Figure 4B). At all meizothrombin des-F1 and R155A-meizothrombin concentrations tested, autocatalytic thrombin formation could be described by a single exponential. Figure 5 shows the pseudo-first-order rate constants $\left(k_{\text {obs }}\right)$ obtained from time courses of autocatalytic thrombin formation determined at varying meizothrombin des-F1 and R155A-meizothrombin

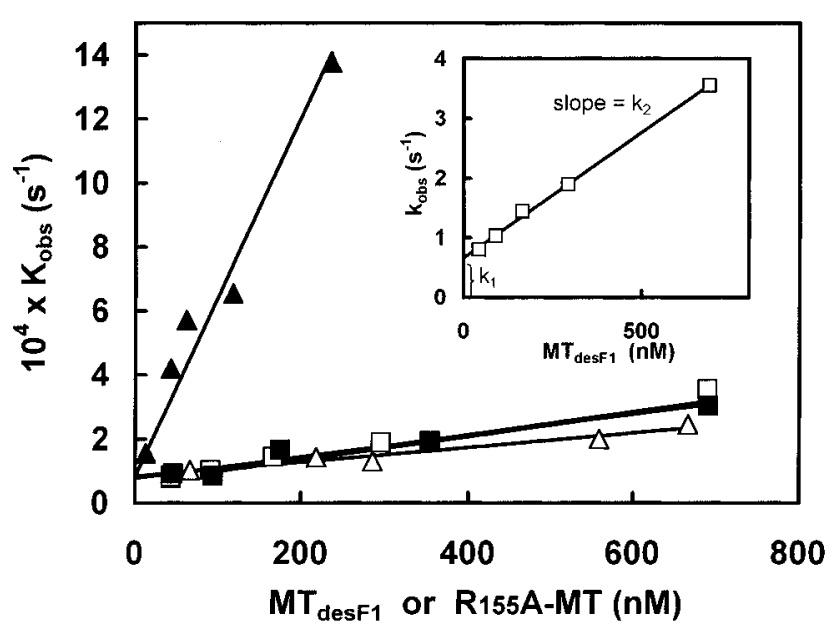

FIGURE 5: Autocatalytic conversion of meizothrombin des-F1 and R155A-meizothrombin into thrombin des-1-13 at varying concentrations. Varying amounts of meizothrombin des-F1 $(\square, \mathbf{\square})$ or R155A-meizothrombin $(\triangle, \mathbf{\Delta})$ were incubated at $37^{\circ} \mathrm{C}$ in a reaction mixture containing $25 \mathrm{mM}$ Hepes ( $\mathrm{pH} 7.7), 175 \mathrm{mM} \mathrm{NaCl}, 0.5$ $\mathrm{mg} / \mathrm{mL}$ ovalbumin, $2.5 \mathrm{mM} \mathrm{CaCl} 2$, and no phospholipids $(\square, \triangle)$ or $25 \mu \mathrm{M}$ DOPS/DOPC $(25 / 75, \mathrm{~mol} / \mathrm{mol})$ vesicles $(\boldsymbol{\square}, \boldsymbol{\Delta})$. Pseudofirst-order rate constants $\left(k_{\mathrm{obs}}\right)$ were obtained from exponential fits of time courses of meizothrombin des-F1 and R155A-meizothrombin dissappearance as in Figure 4. Plotted is $k_{\mathrm{obs}}$ as a function of the meizothrombin des-F1 or R155A-meizothrombin concentration. The inset shows an enlargement of $k_{\text {obs }}$ for meizothrombin des-F1 illustrating the validity of the equation $k_{\mathrm{obs}}=k_{1}+k_{2}[\mathrm{MT}]$ to obtain the intramolecular $\left(k_{1}=\right.$ intercept at $\left.[\mathrm{MT}]=0\right)$ and intermolecular $\left(k_{2}=\right.$ slope of the line) component of autocatalysis. The solid lines represent the best fit of the data to the equation and the $k_{1}$ and $k_{2}$ values obtained are summarized in Table 2 .

concentrations. It appeared that $k_{\mathrm{obs}}$ was neither independent of the meizothrombin concentration (intramolecular autocatalysis, a first-order reaction with $k_{\mathrm{obs}}=$ constant) nor linearly dependent on the meizothrombin concentration (intermolecular autocatalysis, a second-order reaction with $k_{\mathrm{obs}}=k_{2}$ [MT]). This indicates that autocatalytic conversion of meizothrombin des-F1 or R155A-meizothrombin into thrombin is the result of mixed intramolecular and intermolecular autocatalysis. In that case, a plot of $k_{\text {obs }}$ versus meizothrombin concentration should yield a straight line $k_{\mathrm{obs}}=k_{1}+$ $k_{2}$ [MT], in which $k_{1}$ is the first-order rate constant for intramolecular autocatalysis and $k_{2}$ is the second-order rate constant for intermolecular autocatalysis. The occurrence of both intra- and intermolecular autocatalysis and the validity of this equation is demonstrated in the insert of Figure 5 which shows an enlargement of the $k_{\mathrm{obs}}$ of autocatalytic thrombin formation at low meizothrombin desF1 concentrations.

It can be argued that the intramolecular component of autocatalytic conversion of meizothrombin into thrombin is 
not due to meizothrombin itself but is caused by a contaminating proteolytic enzyme present in the reaction mixture, e.g., in the ecarin used for preparation of meizothrombin or in ovalbumin, the carrier protein routinely used in our reaction mixtures. Since addition of excess ecarin or ovalbumin did not affect the time courses of autocatalytic thrombin formation, we exclude this possibility and we conclude that this results of a mixed intramolecular and intermolecular autocatalysis with rate constants $k_{1}$ and $k_{2}$, respectively. The values for $k_{1}$ and $k_{2}$ calculated from Figure 5 and summarized in Table 2 show that the rate constants for intramolecular autocatalysis $\left(k_{1}\right.$, intersection at $[\mathrm{MT}]=$ $0)$ hardly differed for meizothrombin des-F1 or R155Ameizothrombin and were not affected by the presence of phospholipids. In addition, the rate constants for intermolecular autocatalysis $\left(k_{2}\right.$, slope of the line) are similar for meizothrombin des-F1 (with and without phospholipids) and R155A-meizothrombin (without phospholipids). Phospholipids only affected intermolecular autocatalysis of R155Ameizothrombin the rate constant of which was enhanced some 25-fold (Table 2).

\section{DISCUSSION}

Conversion of prothrombin into thrombin by factor $\mathrm{Xa}$ is accompanied by generation of several intermediates and products due to feedback reactions catalyzed by thrombin and meizothrombin. The data presented in this paper provide insight in the potential significance of autocatalytic reactions during the activation of human prothrombin.

In agreement with earlier studies (Walz et al., 1977; Board \& Shaw, 1983; Stevens et al., 1996), thrombin cleavages in human prothrombin were identified at $\mathrm{Arg}^{51}-\mathrm{Thr}^{52} / \mathrm{Arg}^{54}$ $\mathrm{Asp}^{55}, \mathrm{Arg}^{155}-\mathrm{Ser}^{156}$, and $\mathrm{Arg}^{284}-\mathrm{Thr}^{285}$. The rate of cleavage at these peptide bonds is greatly affected by the reaction conditions. In the absence of $\mathrm{Ca}^{2+}$ ions, thrombin relatively efficiently proteolyzes peptide bonds within the fragment 1.2 region $\left(\mathrm{Arg}^{51}-\mathrm{Thr}^{52} / \mathrm{Arg}^{54}-\mathrm{Asp}^{55}\right.$ and $\mathrm{Arg}^{155}$ Ser ${ }^{156}$ ). The presence of calcium ions inhibits the removal of fragment 1 some 25-fold and prevents cleavage at $\mathrm{Arg}^{51}-$ $\mathrm{Thr}^{52} / \mathrm{Arg}^{54}-\mathrm{Asp}^{55}$ in fragment 1. Stevens et al. (1996) observed a similar inhibition for cleavage at $\mathrm{Arg}^{54}-\mathrm{Asp}^{55}$ which is presumably due to sequestering of the peptide bond inside the fragment 1 region upon the binding of calcium to the gla-domain (Stevens et al, 1996). This conformational change, possibly in combination with a reduction of the negative charge of the gla-domain after binding $\mathrm{Ca}^{2+}$ ions, may also be responsible for the 25 -fold inhibition of the rate of cleavage at $\operatorname{Arg}^{155}$ (Silverberg, 1979; Bjork \& Stenflo, 1973; Nelsestuen \& Lim, 1977). The fact that prothrombin is significantly protected from proteolysis by the presence of $\mathrm{Ca}^{2+}$ likely explains why low amounts of fragment 1 are detectable during prothrombin activation in plasma (Boissel et al., 1985; Silverberg, 1979).

It has been reported that during prothrombin activation in plasma fragment 1.2.3 is formed (Rabiet et al., 1986), and it was hypothesized that this may be indicative for a contribution of thrombin/meizothrombin to thrombin formation by cleavage at $\mathrm{Arg}^{284}-\mathrm{Thr}^{285}$. However, comparison of the rates of peptide bond cleavage at $\mathrm{Arg}^{271}-\mathrm{Thr}^{272}$ by factor $\mathrm{Xa}-\mathrm{Va}$ $\left[k=5.5 \times 10^{8} \mathrm{M}^{-1} \mathrm{~s}^{-1}\right.$, cf. Mann et al. (1990) and Table 2] and cleavage at $\operatorname{Arg}^{284}-\mathrm{Thr}^{285}$ by thrombin $\left(k=0.2 \times 10^{3}\right.$
$\mathrm{M}^{-1} \mathrm{~s}^{-1}$ ) shows that on a kinetic basis thrombin itself will hardly contribute to its own formation when factor $\mathrm{Xa}$ is present.

It is possible, however, that meizothrombin can autocatalytically cleave the $\operatorname{Arg}^{284}-\mathrm{Thr}^{285}$ at a faster rate. Meizothrombin has an exposed active site and contains a gladomain that enables its binding to phospholipids which may result in enhancement of its catalytic activity (Tans et al., 1990). Studies on autocatalytic cleavages in and by intact meizothrombin are, however, hampered by the fact that the gla-containing fragment 1 domain is readily cleaved off by autocatalysis (Doyle \& Mann, 1990). In this paper, we show that the $\operatorname{Arg}^{155}-\operatorname{Ser}^{156}$ bond in meizothrombin is indeed cleaved at a high rate. In the presence of $\mathrm{Ca}^{2+}$ ions, the rate of cleavage in $1 \mu \mathrm{M}$ meizothrombin is approximately 25-times higher than thrombin-catalyzed cleavage of the same bond in prothrombin. In contrast to the latter reaction the autocatalytic removal of the fragment 1 domain from meizothrombin yields a constant half-life at all meizothrombin concentrations $\left(t_{1 / 2}=\sim 30 \mathrm{~s}\right)$, which is indicative of a first-order reaction in which each meizothrombin molecule proteolyses itself via intramolecular autocatalysis [cf. Sanny et al. (1975) for intramolecular activation of pepsinogen]. Stevens et al. (1996) also reported an intramolecular mechanism of autocatalysis for cleavage at $\mathrm{Arg}^{54}$. Considering the high rate of intramolecular autocatalysis, meizothrombin is apparently folded in such a way that the fragment 1 region is readily available for entry into the active site and cleavage at $\operatorname{Arg}^{155}$.

The rapid removal of fragment 1 from meizothrombin precludes studies on autocatalytic cleavage of the $\operatorname{Arg}^{284}$ $\mathrm{Thr}^{285}$ bond in intact meizothrombin. This cleavage was, therefore, quantitated in meizothrombin des-F1 and in a recombinant derivative (R155A-meizothrombin) that is resistant to removal of fragment 1 . In the absence of phospholipids, the $\mathrm{Arg}^{284}-\mathrm{Thr}^{285}$ bond was cleaved in meizothrombin des-F1 and R155A-meizothrombin at similar rates. Phospholipids did not affect autocatalytic thrombin formation with meizothrombin des-F1 as substrate and considerably enhanced this reaction in the case of R155Ameizothrombin (Figure 4).

The dependency of the observed rate constant as a function of the meizothrombin concentration (Figure 5) indicates that cleavage of the $\mathrm{Arg}^{284}-\mathrm{Thr}^{285}$ bond results from a combination of an intramolecular first-order reaction (rate constant independent of meizothrombin concentration) and an intermolecular second-order reaction (pseudo-first-order rate constant linearly dependent on the meizothrombin concentration). The rate constant for intramolecular autocatalysis appeared to be similar for both forms of meizothrombin $\left[k_{1}\right.$ $\left.=(0.8-0.9) \times 10^{-4} \mathrm{~s}^{-1}\right]$ and was not affected by the presence of phospholipids (Table 2).

The fact that intramolecular autocatalytic cleavage of $\mathrm{Arg}^{284}-\mathrm{Thr}^{285}$ contributes to the conversion of meizothrombin into thrombin conversion (cf. Figure 5 and Table 2) came somewhat as a surprise. Recently, van de Locht et al. (1996) reported that residues 284-320, which form the truncated A-chain of $\alpha$-thrombin, are located to the back of the molecule, away from the active site. On the basis of this and on crystallographic data available for the complex of fragment 2 with thrombin (Arni et al., 1993), they proposed a hypothetical conformation which would position residues 
271-284 also at the back of the active site in meizothrombin (van de Locht et al., 1996). The very slow rate constant for intramolecular autocatalysis indicates that entry of $\mathrm{Arg}^{284}$ in the active site is indeed an unlikely event. However, our data suggest that it is not impossible and that meizothrombin is apparently sufficiently flexible to allow for cleavage at $\mathrm{Arg}^{284}$. Phospholipids only stimulated intermolecular autocatalysis of R155A-meizothrombin (25-fold increase of $k_{2}$ ). This is not surprising since intermolecular autocatalysis is a bimolecular reaction which, due to coordinated binding of substrate and enzyme and enhanced enzyme-substrate complex formation, will proceed at higher rates at the phospholipid surface [cf. Mann et al. (1990)].

A comparison of the rate constant for meizothrombin autocatalysis at $\operatorname{Arg}^{284}\left(k_{2}=5.6 \times 10^{3} \mathrm{M}^{-1} \mathrm{~s}^{-1}\right)$ and factor $\mathrm{Xa} / \mathrm{Va}$-catalyzed cleavage at $\operatorname{Arg}^{271}\left(k=5.5 \times 10^{8} \mathrm{M}^{-1} \mathrm{~s}^{-1}\right)$ indicates that on a theoretical basis autoproteolysis in meizothrombin can hardly contribute to thrombin formation and will have $50 \%$ contribution after the factor $\mathrm{Xa} / \mathrm{Va}$ complex has catalyzed $10^{5}$ turnovers, i.e., when the concentration of meizothrombin is $10^{5}$ times higher than that of the factor $\mathrm{Xa} / \mathrm{Va}$ complex. Moreover, meizothrombincatalyzed cleavage at $\mathrm{Arg}^{284}$ was not stimulated by factor $\mathrm{Va}$ [alone or in combination with phospholipid vesicles (data not shown)]. Our observation that the fragment 1 domain is rapidly removed from meizothrombin $\left(t_{1 / 2}=\sim 30 \mathrm{~s}\right)$ further reduces the contribution of meizothrombin to thrombin formation since the rate of $\mathrm{Arg}^{284}-\mathrm{Thr}^{285}$ cleavage in meizothrombin des-F1 is even 15 times slower than that in intact meizothrombin (Table 2).

The data obtained in model systems cannot explain the formation of fragment 1.2.3 during prothrombin activation in plasma (Rabiet et al., 1986), which indicates that cleavage at $\mathrm{Arg}^{284}-\mathrm{Thr}^{285}$ contributes to plasma thrombin formation. It is possible that as yet unknown plasma factors may influence the actual rate of peptide bond cleavages in prothrombin. However, further conclusions regarding the contribution of cleavage at $\mathrm{Arg}^{284}-\mathrm{Thr}^{285}$ to thrombin formation have to await kinetic analysis of plasma prothrombin activation.

\section{ACKNOWLEDGMENT}

We thank Dr. J. Godovac-Zimmermann (Protein Labor, Institute for Molecular Biotechnology, Jena, Germany) for amino-terminal sequence analysis.

\section{REFERENCES}

Aronson, D. L., Steven, L., Ball, A. P., Franza, B. R., \& Finlayson, J. S. (1977) J. Clin. Invest. 60, 1410-1418.

Arni, R. K., Padmanabhan, K., Padmanabhan, K. P., Wu, T. P., \& Tulinsky, A. (1993) Biochemistry 32, 4727-4737.

Board, P. G., \& Shaw, D. C. (1983) Br. J. Haematol. 54, 245254.
Bjork, I., \& Stenflo, J. (1973) FEBS Lett. 32, 343-346.

Blake, M. S., Johnston, K. H., Russel-Jones, G. J., \& Gotschlich, E. C. (1984) Anal. Biochem. 136, 175-179.

Boissel, J. P., Lebonniec, N., Rabiet, M. J., Labie, D., \& Elion, J. (1984) J. Biol. Chem. 259, 6519-6525.

Chase, T., \& Shaw, E. (1969) Biochemistry 8, 2212-2224.

Degen, S. J. F., \& Davie, E. W. (1987) Biochemistry 26, 61656177.

DiScipio, R. G., Hermodson, M. A., Yates, S. G., \& Davie, E. W. (1977) Biochemistry 16, 698-706.

Downing, M. R., Butkowski, R. J., Clark, M. M., \& Mann, K. G. (1975) J. Biol. Chem. 250, 8897-9069.

Doyle, M. F., \& Mann, K. G. (1990) J. Biol. Chem. 265, 1069310701.

Esmon, C. T., Owen, W. G., \& Jackson, C. M. (1974) J. Biol. Chem. 249, 606-611.

Fenton, J. W., II, Villanueva, G. B., Ofosu, F. A., \& Maraganore, J. M. (1991) Haemostasis 21 (Suppl. 1), 27-31.

Heldebrant, C. M., Butkowski, R. J., Bajaj, S. P., \& Mann, K. G. (1973) J. Biol. Chem. 248, 7149-7163.

Krishnaswamy, S., Mann, K. G., \& Nesheim, M. E. (1986) J. Biol. Chem. 261, 8977-8984.

Laemmli, U. K. (1970) Nature 227, 680-685.

Lanchantin, G. F., Friedman, J. A., \& Hart, D. W. (1973) J. Biol. Chem. 248, 5956-5966.

Mann, K. G., Nesheim, M. E., Church, W. R., Haley, P., \& Krishnaswamy, S. (1990) Blood 76 (1), 1-16.

Morita, T., Iwanaga, S., \& Suzuki, T. (1976) J. Biochem. 79, 10891108.

Nelsestuen, G. L., \& Lim, T. K. (1977) Biochemistry 16, 41644171.

Pletcher, C. H., \& Nelsestuen, G. L. (1982) J. Biol. Chem. 249, 5342-5345.

Rabiet, M. J., Blashill, A., Furie, B., \& Furie, B. C. (1986) J. Biol. Chem. 261, 13210-13215.

Rhee, M. J., Morris, S., \& Kosow, D. P. (1982) Biochemistry 21 , 3437-3443.

Rosing, J., Tans, G., Govers-Riemslag, J. W. P., Zwaal, R. F. A., \& Hemker, H. C. (1980) J. Biol. Chem. 255, 274-283.

Rosing, J., Zwaal, R. F. A., \& Tans, G. (1986) J. Biol. Chem. 261, 4224-4228.

Sanny, C. G., Hartsuck, J. A., \& Tang, J. (1975) J. Biol. Chem. 250, 2635-2639.

Silverberg, S. A. (1979) J. Biol. Chem. 254, 88-94.

Smith, P. K., Krohn, R. I., Hermanson, G. T., Malia, A. K., Gartner, F. H., Provenzano, M. D., Fujimoto, E. K., Goeke, N. M., Olsen, B. J., \& Klenk, D. C. (1985) Anal. Biochem. 150, 76-85.

Stevens, W. K., Côté, H. C. F., MacGillivray, R. T. A., \& Nesheim, M. E. (1996) J. Biol. Chem. 271, 8062-8067.

Suttie, J. W., \& Jackson, C. M. (1977) Physiol. Rev. 57, 1-70.

Tans, G., Janssen-Claessen, T., Hemker, H. C., Zwaal, R. F. A., \& Rosing, J. (1991) J. Biol. Chem. 266, 21864-21873.

Tans, G., Nicolaes, G. A. F., Thomassen, M. C. L. G. D., Hemker, H. C., van Zonneveld, A. J., Pannekoek, H., \& Rosing, J. (1994) J. Biol. Chem. 269, 15969-15972.

Thaler, E., \& Schmer, G. (1975) Br. J. Haematol. 31, 233-243. van de Locht, A., Stubbs, M. T., Bauer, M., Bode, W. (1996) J. Biol. Chem. 271, 3413-3416.

Walz, D. A., Hewett-Emmett, D., \& Seegers, W. H. (1977) Proc. Natl. Acad. Sci. U.S.A. 74, 1969-1972.

BI971948H 